\title{
Evropski vidiki regionalizacije Slovenije
}

UDK: 352(497.12) : 005

\author{
Ciril Ribičič \\ Ustavno sodišče Republike Slovenije \\ ciril.ribicic@us-rs.si
}

Ne samo na področju lokalne samouprave, temveč tudi pri vseh drugih reformnih prizadevanjih je sklicevanje na evropske izkušnje postalo moderno. Skoraj vsakdo se pri zagovarjanju svojih stališč že sklicuje na to, da so natančno takšna, kot so uveljavljena $\vee$ Evropi. Za takšnim sklicevanjem pogosto ni niti minimalnega poznavanja ureditve, delovanja in razvoja držav, na katere se nekdo sklicuje. Zato takšno idealiziranje Evrope ni prepričljivo, še bolj pa je za utrjevanje evropske pripadnosti škodljivo, da se vse vlade evropskih držav pri najbolj nepopularnih ukrepih izgovarjajo, da tako terja Evropa. Pomembno je opozoriti, da kaže Evropa več raznolikih obrazov, na področju lokalne samouprave še posebej in da ni težko najti primerov, ki potrjujejo ravno tisto, kar nekdo sam misli, da je edino prav in zveličavno.

$\checkmark$ tem prispevku presojamo zamisel o regionalizaciji Slovenije z evropskih vidikov $v$ dveh pomenih. Evropski vidik regionalizacije $v$ širšem smislu se tiče vprašanja, ali in v kakšni meri Slovenija pri graditvi sistema lokalne samouprave nasploh in pri uvajanju pokrajin posebej, upošteva evropske izkušnje. Evropski vidik v ožjem smislu pa se tiče vprašanja, ali in v kakšni meri je Slovenija prilagodila svoj sistem lokalne samouprave nasploh in regionalizacije posebej, svojemu vključevanju v Evropsko unijo.

Svet Evrope je veliko storil za medsebojno prenašanje izkušenj evropskih držav glede urejanja, delovanja in razvoja lokalne samouprave (prim. Vlaj: 2004, s. 283 in nasl.). Pri tem je še posebej veliko pozornost posvetil lajšanju težav pri reformiranju lokalne samouprave $\vee$ državah, ki so vstopile $\vee$ Svet Evrope po padcu Berlinskega zidu. Ne glede na to, da $\vee$ Evropi tradicionalno sobivajo dokaj različni modeli lokalne samouprave, kot so angleški, nemški, francoski in skandinavski, je Svetu Evrope uspelo izbrati tista načela in praktične izkušnje, ki so navedenim modelom skupni in zato podlaga in okvir vsake uspešne reforme lokalne samouprave. Ta načela in praktične izkušnje so zbrane $v$ 


\section{Ciril Ribičič}

\section{Evropski vidiki regionalizacije Slovenije}

Evropski listini lokalne samouprave iz 1985. leta ter posodobljene in konkretizirane $v$ številnih usmeritvah, oblikovanih $v$ okviru Kongresa lokalnih in regionalnih oblasti Evrope'.

Pri tem ne gre podcenjevati aktivnosti, ki jih je v tem okviru namenil Svet Evrope širši, regionalni samoupravi. Toda kljub temu je izmenjavanje evropskih izkušenj na tem področju bistveno manj uspešno, kot takrat, ko gre za temeljno lokalno samoupravo in najožjo, torej občinsko raven delovanja lokalnih skupnosti. Najboljša ilustracija tega so dolgoletna neuspešna prizadevanja za oblikovanje evropskega dokumenta, ki bi zbral načela in izkušnje regionalne samouprave in za katerega je že danes jasno, da ga takrat, ko (če) bo sprejet, nikakor ne bo mogoče primerjati z Evropsko listino lokalne samouprave, niti po obliki, niti po vsebini.

Kljub težavam pri koncipiranju evropske zamisli regionalne samouprave se zdi nesporno v Evropi preverjeno izhodišče, da se slovenski prostor z dvema milijonoma prebivalcev ne bi smel zadovoljiti s sistemom lokalne samouprave na eni sami ravni ${ }^{2}$. Takšen sistem je pomanjkljiv, skoraj invaliden in ustvarja, če povzamemo po dr. Janezu Šmidovniku, škodljive sistemske napetosti in "pritiske na center države«, ki jih brez ustavnih sprememb ne bo mogoče odpravljati, "pač pa se bomo vrteli $v$ začaranem krogu nerešljivih problemov« (Šmidovnik: 1995, s. 261). Mogoče je argumentirano zastopati tezo, da je neevropsko, da v Sloveniji ni pokrajin oziroma drugih širših lokalnih skupnosti. $\mathrm{Na}$ tem področju torej Slovenija ne izpolnjuje minimalnih evropskih standardov organiziranja lokalne samouprave. To je slabo še posebej zato, ker je Slovenija močno raznolika država s precejšnjo tradicijo pokrajin, ki izpolnjujejo vse potrebne kriterije, vključno s subjektivno pripadnostjo njihovih prebivalcev.

$\checkmark$ takšni situaciji je bilo seveda manj aktualno drugo vprašanje, namreč vprašanje, kakšen regionalizem, uveljavljen $\vee$ najpomembnejših evropskih državah, za Slovenijo ne bi bil primeren. To vprašanje postaja aktualno danes, ko se $\vee$ Sloveniji odločamo o tem, ali naj se izvede njena regionalizacija. Evropske izkušnje na področju regionalizma $\vee$ večjih državah so za Slovenijo v marsičem nesprejemljive oziroma neuporabne zaradi njene majhnosti. To velja za delovanje nemških in avstrijskih dežel, ki imajo položaj federalnih enot, ki konstituirajo državo. Toda tudi regije, italijanske na primer, ki niso federativne enote, imajo lahko zelo široke državne pristojnosti in po svoji oblastni organiziranosti spominjajo na državo $v$ malem in so za organiziranje slovenskih

1 Prim. C. Ribičič, Evropska listina lokalne samouprave in Slovenija, v: Vodnik: 2001, s. 114 in nasl.

2 J. Šmidovnik opozarja, da imajo tudi centralistično urejene države s šibkejšo lokalno samoupravo regije kot "pomemben korektiv za omejevanje centralistične togosti državnega upravljanja». (Šmidovnik: 1995, s. 102) 
pokrajin preveč ambiciozen in neprimeren vzorec. Samo neupoštevanje te druge, zgornje premise pri oblikovanju pokrajin, je lahko $v$ preteklosti vodilo do slikanja povsem nerealnih strahov ${ }^{\mathbf{3}}$ o tem, da bi regionalizacija Slovenije krepila separatistične težnje. Teza o ogrožanju enotnosti komaj nastale države je pri sprejemanju Ustave $v$ letu 1991 prispevala k zmagi nasprotnikov regionalizaci$\mathrm{je}^{4}$. Kot da Slovenija pri svoji regionalizaciji ne bi bila soočena z dovolj realnimi dilemami, povezanimi z koncipiranjem pokrajin, določanjem njihovih pristojnosti, števila, sedežev, sodelovanja z državno upravo, vpliva na delovanje državnih organov $^{\mathbf{5}}$ itd.

Seveda pa ni mogoče veliko storiti, dokler se ne spremeni ustavna ureditev, po kateri je pokrajina tisto, o čemer se lahko sporazumejo občine, saj občina odloča ne le o teritorialnem oblikovanju posameznih pokrajin, pač pa tudi o nalogah, o organizaciji in o delovanju posameznih pokrajin " (Šmidovnik, Podoba pokrajine, v: Vodnik: 2001, s. 28). To so prepričljivo pokazali večkratni poskusi uvajanja pokrajin z zakonom.

Prizadevanja za ustanovitev pokrajin so se že večkrat izjalovila, prvič ob pripravljanju in sprejemanju ustave in potem še večkrat, ko ni bilo mogoče doseči zahtevane parlamentarne večine za spremembo ustave. Kako je mogoče razložiti, da ni prišlo do ustanovitve pokrajin, čeprav je vrsta multidisciplinarnih analiz domačih strokovnjakov in evropskih izvedencev dokazala, da bi bilo to za Slovenijo in njeno vključevanje $v$ evropske integracije, nujno in koristno? Bržkone je bil glavni vzrok v tem, da so politične stranke vsakokratne opozicije odklanjale oblikovanje pokrajin, ker hočejo biti na oblasti takrat, ko bo sprejeta odločitev o oblikovanju pokrajin, da bi tako imele več vpliva na odločanje o pristojnostih in velikosti pokrajin. Če bi se tudi tokratna opozicija postavila na enako stališče, torej na stališče, da mora biti na oblasti, ko bo

3 Med takšne nerealne strahove velja prišteti tudi očitke, da bi ustanavljanje pokrajin lahko vodilo do restavracije starega ustavnega sistema, tistega pred letom 1991, do vračanje v predsedniški sistem, kontrarevolucijo in obnavljanje Jugoslavije. (Prim. Ribičič: 1994, s. 125)

4 Pristaši uvedbe pokrajin $s(m) o v$ ustavni razpravi zagovarjali pristop, da naj Ustava omeji možnosti centralizacije tako, da ne le omogoči, temveč tudi zagotovi nastanek pokrajin ("Slovenija ima pokrajine. «). Opozarjali $s(m)$ o na to, da je ob načelu delitve oblasti na horizontalni ravni še kako pomembna tudi vertikalna delitev oblasti (Nastajanje slovenske ustave: 2001, s. 1090 in nasl.).

5 Če je kaj od izkušenj iz obdobja komunalnega sistema lahko zanimivo tudi za razvoj lokalne samouprave $v$ novih razmerah, potem so to oblike vplivanja občin na odločanje $v$ nacionalnem parlamentu. Te so se $v$ 70-ih letih prejšnjega stoletja razvijale od različnih oblik neformalnega vplivanja, prek zasedanja delegatov občin do oblikovanja zbora občin, kot enakopravnega zbora takratne slovenske skupščine. Gre za rešitve, ki jih je v Sloveniji postopoma oblikovala praksa in jih $v$ začetku v drugih delih Jugoslavije niso poznali. Čeprav dvodomnost slovenskega parlamenta ni realna do uveljavitve pokrajin, ne le normativno, temveč tudi v praksi, gre za rešitev, brez katere ni mogoče vsebinsko zaokrožiti reforme lokalne samouprave v Sloveniji in ne razrešiti problema Državnega sveta, ki je nastal kot nadomestek zbora pokrajin (Prim. Nastajanje slovenske ustave: 2001, s. 1108). 


\section{Ciril Ribičič}

\section{Evropski vidiki regionalizacije Slovenije}

prišlo do njihovega oblikovanja, pokrajine spet ne bi mogle biti uvedene. In tako naprej v neskončnost.

Vendar je takšno gledanje enostransko. Za opozicijo je še kako pomembno, da je država organizirana decentralizirano, ker lahko samo $v$ takem primeru $\vee$ tistih močnih in avtonomnih lokalnih skupnostih, $\vee$ katerih organih ima večinsko podporo, lažje preživi obdobje, ko je na državni ravni v opoziciji in se usposablja za vladanje $v$ času, ko se bo to spremenilo. Zlasti iz italijanske prakse so znani primeri, ko je bilo za preživetje in modernizacijo levih političnih strank izrednega pomena, da so bile na oblasti v pomembnih regijah in pokrajinah $\vee$ obdobju, ko zelo dolgo niso bile $v$ sestavi vladnih koalicij na nacionalni ravni.

Napake, ki so bile storjene zaradi neupoštevanja izkušenj, zapisanih $v$ Evropski listini lokalne samouprave, imajo lahko bistveno bolj usodne posledice ravno zato, ker je ustava onemogočila nastanek pokrajin. Na kaj mislim? Oblikovanje (pre)velikega števila (pre)majhnih občin, ki so zamenjale nekdanje (nedvomno prevelike in preveč zbirokratizirane) komune, je poglobilo prepad med nemočnimi, dr. Stane Vlaj bi rekel "oskubljenimi« občinami in vse bolj centralizirano državo. Ekonomska in finančna odvisnost majhnih občin od države onemogoča uveljavljanje avtonomije, značilne za lokalno samoupravo v razvitih evropskih državah, pa tudi delovanje načela subsidiarnosti. Na takšne občine država, tudi če bi želela, ne bi mogla prenesti izvrševanja kakšnih pomembnejših pristojnosti. Področje ekologije (prim. dr. Dušan Plut, Slovenija in sonaravna evropska politika, Regionalizem, 1998, s. 33) je lahko zgovoren primer, ki kaže, kako so lahko evropski standardi ogroženi takrat, ko majhne, samostojnega obstoja in razvoja nesposobne občine, za majhen denar razprodajajo kmetijska zemljišča in zaradi reševanja svojega nezavidljivega finančnega položaja pristajajo na uničevanje okolja.

Nobenega dvoma ni, da so negativni učinki drobitve lokalne samouprave v Sloveniji bolj usodni ravno zato, ker ne obstoja druga raven širše lokalne samouprave. Če je bilo obdobje od osamosvojitve do danes posvečeno drobitvi Slovenije, je čas, da se z vstopom $v$ Evropsko unijo začne Slovenija ukvarjati $s$ povezovanjem, utemeljenim na decentralizaciji. Doslej se je veliko pozornosti posvečalo predvsem horizontalni delitvi oblasti na zakonodajno, izvršilno in sodno, poslej bi se morali več ukvarjati tudi z vertikalno delitvijo oblasti (med centralno oblastjo in lokalno samoupravo). K takšnemu razvoju lahko pomembno prispeva ustanovitev pokrajin.

$S$ tem smo pri evropskih vidikih v ožjem smislu. Odsotnost pokrajin je še posebej boleča v zvezi z vključitvijo v Evropsko unijo. Gre za pristop k enotnemu gospodarskemu prostoru, $v$ katerem poteka svoboden pretok proizvodov, storitev, idej in ljudi. $\vee$ novih razmerah je vsak del Slovenije pod neposrednim 
vplivom tujega okolja. $V$ razmerah odprtega sodelovanja in svobodne konkurence postanejo pomanjkljivosti $v$ organiziranju očitnejše in nevarnejše, kot so bile, dokler so jih varovale državne meje.

Opozorila o tem, kakšne bodo posledice invalidne organiziranosti lokalne samouprave, so bila dovolj zgodnja in jasna: "Če bo Slovenija vstopila v Evropsko zvezo z invalidno organiziranostjo, bo nepripravljena dočakala odpravo klasičnih meja z Italijo, Avstrijo in Madžarsko ter nekaj let pozneje tudi s Hrvaško." (Ribičič: 2003, s. 45) Naj citiramo še eno, skoraj dramatično opozorilo: Slovenija ne bi smela dočakati vključitve $\vee$ Evropsko unijo brez pokrajin; ustrezno organizirana lahko Slovenija doseže »ideal Zedinjene Slovenije v združeni Evropi; $\vee$ nasprotnem primeru bo vključitev Slovenije $v$ Evropsko unijo vodila do podreditve velikega dela ozemlja, na katerem živijo Slovenci, tujim političnim interesom in kapitalu« (Regionalizem, 1998, s. 228). Opozorila niso bila upoštevana, je pa toliko pomembneje, da se zamujeno nadoknadi čim prej. Izkoristiti je treba dodatni čas, ki ga ima na razpolago Slovenija, ker se nekateri vidiki odpiranja meja in integriranja slovenskega trga $v$ evropski uveljavljajo $z$ zamikom (vključitev $\vee$ Schengenski prostor, vključitev $v$ evro območje, odpravljanje ovir v starih članicah Evropske unije za svoboden pretok delovne sile itd.). Toda tudi ta čas se hitro izteka.

Drugi evropski vidik v ožjem smislu zadeva (ne)sposobnost Slovenije, da uspešno konkurira za evropska sredstva. Ta se praviloma ne dajejo državi ali lokalnim skupnostim na pamet, temveč za realizacijo konkretnih projektov. Ravno na regionalni ravni je realno pričakovati, da bodo ljudje in občine sposobni povezati prizadevanja za pripravo takšnih kakovostnih programov, ki jih bodo (so)financirali strukturni skladi Evropske unije. Na prvi pogled je očitno, da ogromna večina občin za kaj takega ni ustrezno usposobljena. Tudi zato velja z ustanavljanjem pokrajin pohiteti.

$\mathrm{S}$ tem vidikom je povezan problem zagotavljanja enakomernejšega regionalnega razvoja Slovenije. Brez pokrajin, na katere se bo prenesel pomemben del ekonomske moči in odgovornosti za lasten razvoj, se bodo še naprej poglabljale razvojne razlike med državnim središčem in obmejnimi pokrajinami, ki se spreminjajo $v$ periferijo. Evropska sredstva za manj razvite lahko pri tem pomembno pomagajo, pri čemer je očitno, da bo Slovenija kot celota zaradi razvite osrednje pokrajine vse manj upravičena do teh sredstev, za ogromno večino drugih slovenskih pokrajin pa so dodatne razvojne spodbude nujno potrebne in vsestransko upravičene. Pri tem Sloveniji ni treba ustanavljati pokrajin na umeten način, zaradi špekulacij $\vee$ zvezi s črpanjem evropskih sredstev, kar včasih očitajo na primer Irski, saj v našem primeru obstajajo prepričljivi notranji razlogi za njihov nastanek. 


\section{Ciril Ribičič \\ Evropski vidiki regionalizacije Slovenije}

Pokrajine bi lahko spodbudile lasten in skupen razvoj (prim. Bugarič, B., Ekonomski vidiki regionalizma, v: Regionalizem, 1998, s. 121), tudi v povezavi z ustreznimi lokalnimi skupnostmi v sosednjih državah, česar razdrobljene občine niso sposobne. Da niti ne omenjam tega, do kakšne mere je lahko danes Slovenija enakopravna pri oblikovanju čezmejnih evro regij, skupaj z območji v sosednjih državah, ki so vse organizirane tudi na regionalnih ravneh ${ }^{\mathbf{6}}$.

S spremembo 143. člena ustave se odpira proces oblikovanja pokrajin, za kar so se $v$ zadnjih 15 letih zavzemale številne pobude, analize, posvetovanja in zborniki. Vendar pa velja sedaj pozornost usmeriti naprej. Zato je smiselno posebej poudariti, da ni sprejemljivo ustanavljanje kakršnih koli pokrajin in na kakršen koli način. Dvotretjinska večina, določena za sprejemanje najpomembnejše zakonodaje, povezane z ustanavljanjem pokrajin, zagotavlja, da ne bo prišlo do ureditve, ki bi počivala na ozkih interesih vladajočih političnih struktur (volilna geometrija) ali do razlastitve občin ${ }^{7}$. Aktualni pa obstajata drugi dve nevarnosti.

Izkušnje s pretiranim drobljenjem občin upravičeno zbujajo skrb, da se podobne težnje ne bi uveljavile tudi pri oblikovanju pokrajin. To ne bi bilo vprašljivo samo z vidika načelnih evropskih usmeritev, temveč tudi v nasprotju $s$ konkretnimi opozorili izvedencev Sveta Evrope o tem, da pokrajine $v$ Sloveniji ne bi smele šteti manj kot po 100.000 prebivalcev.

Druga, vsaj tako pomembna nevarnost je, da bi se poskusilo oblikovanje pokrajin izkoristiti za bolj učinkovito obvladovanje in podrejanje lokalnih skupnosti državi in njeni upravi. Zlasti hrvaške izkušnje na področju razvoja županij opozarjajo na nevarnost, da se širša lokalna samouprava lahko deformira tako, da se spremeni v ubogljiv podaljšek državne birokracije. To opozorilo velja resno upoštevati pri razmišljanjih o pokrajini kot dvoživki, ki bi bila hkrati širša samoupravna lokalna skupnost in upravni okraj.

Ko bodo pokrajine ustanovljene in bodo zaživele, se bo postopno ponovno odprlo vprašanje njihove zastopanosti in vpliva na sprejemanje odločitev $v$ državnem parlamentu. Ne gre pozabiti, da je bila v nekdanji jugoslovanski federaciji ravno Slovenija tista, ki je dajala največji poudarek policentričnemu razvoju

6 Pregled organiziranja regionalne oblasti, ki obstajajo v državah članicah Evropske unije med centralno državno oblastjo in manjšimi lokalnimi skupnostmi: Vlaj, Decentralizacija, Evropa in mi, v: Pokrajina: 2004, s. 158.

7 Tako je raziskovalna skupina pri Inštitutu za javno upravo pri Pravni fakulteti v Ljubljani (dr. Rajko Pirnat, dr. Franc Grad, dr. Gorazd Trpin, dr. Senko Pličanič in mag. Erik Kerševan) izdelala pregled nalog in pristojnosti, ki bi jih država prenesla na pokrajine. Pregled zajema na stotine nalog in pristojnosti, opredeljenih $v$ več kot 50 zakonih (Dokumenti in študije o pokrajinah v Sloveniji 2000-2004, (ur. R. Lavtar), Ministrstvo za notranje zadeve, Ljubljana, 2004, s. 265 in nasl.) 
in vplivu lokalnih skupnosti na državno odločanje (zasedanje delegatov občin, zbor občin). Tudi ob sprejemanju ustave $v$ letih 1990/91 je bil vseskozi prisoten predlog o oblikovanju regionalnega zbora kot druge parlamentarne zbornice, ki bi okrepila vpliv lokalnih in regionalnih interesov na račun pretiranega vpliva vrhov političnih strank $v$ državnem zboru. $\vee$ prehodnem obdobju bodo pokrajine lahko svoj vpliv na odločanje državnega zbora uveljavljale prek državnega sveta.

Skratka, oblikovanje pokrajin na način, ki bi vodil do novih drobitev in delitev, do krepitve državne birokracije, namesto do povezovanja in krepitve danes šibke lokalne samouprave, bi bilo še en zgrešeni udar, pa naj ga ocenjujemo z evropskih ali s slovenskih vidikov.

Dr. Ciril Ribičič je sodnik Ustavnega sodišča Republike Slovenije ter redni profesor za ustavno pravo na Pravni fakulteti v Ljubljani, na kateri poučuje neprekinjeno že 30 let. Je avtor številnih del s področja ustavnega prava. Bil je predsednik katedre za ustavno pravo in predsednik Društva za ustavno pravo ter $v$ ustavni komisiji, ki je pripravila veljavno ustavo, vodil skupino za državno ureditev. Za ustavnega sodnika je bil na predlog katedre za ustavno pravo izvoljen 19. decembra 2000. 


\section{Ciril Ribičič \\ Evropski vidiki regionalizacije Slovenije}

\section{Literatura in viri}

- Bugarič, B. (1998): Ekonomski vidiki regionalizma. V: Regionalizem v Sloveniji. Str. 121-130. Zbirka Pravo in politika. Uradni list Republike Slovenije, Ljubljana.

- Cerar, M., Perenič, G., ed. (2001): Nastajanje slovenske ustave, Izbor gradiv Komisije za ustavna vprašanja, III. zvezek, Ljubljana.

- Kocjančič, R., Ribičič, C., Grad, F., Kaučič, I. (2005): Ustavno pravo, Fakulteta za upravo, Ljubljana.

- Lavtar, R. (2004): Deset let lokalne samouprave: vizija 1994, praksa 2004. 199 str. Skupnost občin Slovenije, Maribor.

- $\quad$ Plut, D. (1998): Slovenija in sonaravna evropska politika. V: Slovenija: pokrajine in ljudje. 735 str., Mladinska knjiga, Ljubljana.

- Ribičič, C. (1998): Regionalizem v Sloveniji: zbornik. 284. str. Zbirka Pravo in politika. Uradni list Republike Slovenije, Ljubljana.

- Ribičič, C. (1994): Centralizem zoper Slovenijo. Ljubljana,.

- Ribičič, C. (2003): Mozaik ustavnih sprememb, PP, Ljubljana.

- Šmidovnik, J. (1995): Lokalna samouprava. Zbirka: Pravna obzorja 4, 274 str. Cankarjeva založba, Ljubljana.

- Vlaj, S. (2001): Vodnik po slovenski lokalni samoupravi. 136 str., Inštitut za lokalno samoupravo pri Visoki upravni šoli, Ljubljana.

- Vlaj, S. (2004): Pokrajina: druga raven lokalne samouprave. 161 str. Inštitut za lokalno samoupravo pri Fakulteti za upravo, Ljubljana.

- Vlaj, S. (2004): Lokalna samouprava: teorija in praksa. / Spremenjena in dopolnjena izd./ 376 str. Fakulteta za upravo, Ljubljana.

- Vlaj, S. (2004): Decentralizacija, Evropa in mi. V: Pokrajina: druga raven lokalne samouprave. str. 158. Inštitut za lokalno samoupravo pri Fakulteti za upravo, Ljubljana. 


\title{
European aspects of the regionalization of Slovenia
}

UDK: 352(497.12) : 005

\author{
Ciril Ribičič \\ Ustavno sodišče Republike Slovenije \\ ciril.ribicic@us-rs.si
}

It has become very fashionable in Slovenia to refer to European experiences not only in the area of local self-government, but in respect of all other reform efforts as well. When justifying their viewpoints nearly everyone refers to the fact that these are precisely the same viewpoints as those established elsewhere in Europe. Such references are often made without a minimum knowledge of the arrangements, functioning and development of the countries to which they refer. Such idealising of Europe is therefore not convincing. What's more, what works to erode European integration is the fact that all European governments inevitably claim, when adopting highly unpopular measures, that Europe requires them to do so. It's important to point out that Europe puts on many a diverse face, particularly as regards matters of local self-government, and that it's not difficult to find examples which succeed in proving exactly that which some individual considers to be the only right and exalted answer.

This contribution assesses the idea of Slovenian regionalization from European perspectives in two senses. The European perspective of regionalization in the broader sense relates to the question whether, and to what extent, Slovenia takes into account the European experiences in the process of establishing a system of local self-government in general; and in the process of introducing regions in particular. The European perspective on regionalization in the narrow sense relates to the question whether and to what extent Slovenia has adapted its system of local self-government in general, and regionalization in particular, to its integration into the European Union.

The Council of Europe has significantly contributed to the mutual sharing of experiences of European countries as regards organisation, operation and development of local self-government (cf. Vlaj: 2004, p. $283 \mathrm{ff}$.). In this context it has paid a great deal of attention to the solving of difficulties in the process of reforming local self-government in those countries that joined the Council of 


\section{Ciril Ribičič}

\section{European aspects of the regionalization of Slovenia}

Europe after the fall of the Berlin Wall. Irrespective of the fact that rather different models of local self-government have traditionally co-existed in Europe, such as the English, German, French and Scandinavian schemes, the Council of Europe has succeeded in selecting those principles and practical experiences which are common to the abovementioned models and which represent the basis and framework of each successful reform of local selfgovernment. These principles and practical experiences have been collected in the European Charter of Local Self-Government from 1985 and updated and concretized in numerous policies developed within the framework of the Congress of Local and Regional Authorities of Europe'

We must not, however, underestimate the activities which, in this context, the Council of Europe devotes to wider regional self-government. In spite of this, the sharing of European experiences in this area is considerably less successful than in cases of basic local self-government and the narrowest level, the municipal or community level. This point is best illustrated by the ongoing unsuccessful efforts toward the preparation of a European document which would comprise the principles and experiences of regional selfgovernment, in respect of which it is already clear that even if adopted, will not bear any resemblance nor exhibit grounds for comparison to the European Charter of Local Self-Government, neither in form nor in content.

Despite difficulties related to the drafting of a European idea of regional self-government, the following starting point put to the test in Europe seems undisputed, namely that Slovenia, with its two million inhabitants, should not opt for the system of local self-government on a single level ${ }^{2}$. Such a system is deficient, almost invalid and, according to Dr. Janez Šmidovnik, creates harmful system tensions and "pressures on the state centre" which will be impossible to eliminate without constitutional amendments; instead "we will be caught in the vicious circle of unsolvable problems" (Šmidovnik: 1995, p. 261). The thesis that it is not European, that there are no regions or other wider local communities in Slovenia, is based on sound arguments. In this area Slovenia does not meet the minimum European standards in respect of local self-government organisation. This bodes particularly badly in light of the fact that Slovenia is a rather heterogeneous country with a considerably long tradition of regions which fulfil all the necessary criteria, including that related to the subjective affiliation of their inhabitants.

1 Cf. C. Ribičič, Evropska listina lokalne samouprave in Slovenija (The European Charter of Local Self-Government and Slovenia), in: Vodnik: 2001, p. $114 \mathrm{ff}$.

$2 \mathrm{~J}$. Šmidovnik notes that even centralised states with weaker local self-government have regions as "an important means of limiting the centralistic rigidity of state governance" (Šmidovnik: 1995, p. 102). 
In these circumstances the second issue at hand has received less attention, namely the issue of determining what kind of regionalism established in the most important European countries would not be suitable for Slovenia. This issue is becoming increasingly more important, when today Slovenia has to decide whether to carry out its plan for regionalization. The European experiences in the area of regionalism from larger countries are, in many ways, not acceptable for Slovenia or even prove pointless because of the country's small size. This holds true for the functioning of German and Austrian states which have the status of federal units which comprise the country. But even regions - those in Italy for instance, which are not federal units - can have extensive state competences, mirroring the state on a small scale with regard to their organisation of authority, but this is an overly ambitious and unsuitable model for the organisation of Slovenian regions. Failure to consider the abovementioned second premise in the creation of regions has, in the past, led to entirely unreasonable fears ${ }^{\mathbf{3}}$ regarding the assumption that the regionalization of Slovenia would strengthen separatist tendencies. The thesis on the endangering of national unity of this then recently founded country contributed to the victory of opponents of regionalization ${ }^{\mathbf{4}}$ in the process of adopting the Constitution in 1991. This as if Slovenia, in its regionalization, were not facing enough real dilemmas related to the planning of regions, and defining competences, number, seats, co-operation with the state administration, its impact on the functioning of state authorities ${ }^{\mathbf{5}}$ etc.

3 Such unreal fears also include the reproaches that the establishment of regions could lead to the restoration of the old constitutional system, the one in force before 1991, and a return to the presidential system, counter-revolution and the restoration of Yugoslavia (Cf. Ribičič: 1994, p. 125).

4 In the constitutional debate supporters of the introduction of regions argued for an approach on the basis of which the Constitution would limit the possibilities of centralisation so that it would not only enable but also ensure the establishment of regions ("Slovenia has regions."). It has been warned that in addition to the principle of division of authority at the horizontal level the vertical division of authority is also very important (Nastajanje slovenske ustave (Creating the Slovenian Constitution: 2001, p. 1090 ff.).

5 If there is anything interesting from the communal system period for the development of local self-government in these new circumstances, then it is the forms of municipal influence on the decision-making process in the national parliament. In the 1970s, these comprised informal influence, meetings of municipal delegates and the establishment of the Chamber of Municipalities as an equal chamber of the then Slovenian Assembly. These were the solutions which were gradually created in practice in Slovenia and initially unknown in other parts of Yugoslavia. Although a two-chamber Slovenian parliament is not possible until the introduction of regions, not only normatively but also in practice, this is a solution without which it is impossible to conclude substantively the reform of local self-government in Slovenia and solve the problem of the National Council which was established as a substitue for the Chamber of Regions (Cf. Nastajanje slovenske ustave (Creating the Slovenian Constitution): 2001, p. 1108). 


\section{Ciril Ribičič}

\section{European aspects of the regionalization of Slovenia}

Of course not much can be done until amendments have been made to the constitutional organisation according to which the municipalities may decide on the regions, since "municipalities decide not only on the territorial organisation of individual regions but also on the tasks, organisation and functioning of individual regions" (Šmidovnik, Podoba pokrajine (/mage of the Region), in: Vodnik: 2001, p. 28). This has been convincingly proven by numerous attempts to introduce regions by means of the law.

Efforts to establish regions have failed: the first time in the process of preparing and adopting the Constitution; and several times following, when it was impossible to obtain the necessary majority in parliament for a constitutional amendment. How can one hope to explain how it is that regions have never been established, the process never taken place, despite the fact that a number of multidisciplinary analyses of Slovenian and European experts have proven that this is both necessary and useful for Slovenia and its inclusion in European integration processes. Perhaps the main reason lay in the fact that the opposition parties have always rejected the establishment of regions because they hoped to be in power when the decision on the establishment of regions was adopted, such that they could exert greater influence on the decision-making process regarding competences and region sizes. If the present opposition were also to adopt the same view - that it must be in power when the regions are established - regions would not be introduced yet again. And we would go on and on, ad infinitum.

But such a viewpoint is one-sided. It is very important for the opposition that the country is organised on a decentralized basis, because it is precisely in strong and autonomous local communities in which it has majority support that it can easier survive the period when it is in opposition at the state level, and train for governance for changed situation some time in the future. Practical examples from the Italian experience show how vastly important it was for the survival and modernisation of left-wing political parties that they remained in power in important regions and provinces in the period in which they had not long been part of a government coalition at the national level.

The mistakes which have been made because the experiences documented in the European Charter of Local Self-Government had not been taken into account may have considerably more fatal consequences precisely because the Constitution has rendered the establishment of regions impossible. What do I have in mind? The establishment of (too) many (overly) small municipalities which have replaced the former (undoubtedly excessively large and bureaucratized) communities has widened the gap between the weak - or in 
the words of Dr. Stane Vlaj "impoverished" - municipalities, and the increasingly more centralized state.

Economic and financial dependence of small municipalities on the state renders it impossible to establish an autonomy characteristic of local selfgovernment in developed European countries, as well as the functioning of the principle of subsidiarity. Even if it wished to do so, the state could not transfer the execution of important competences to such municipalities. The area of ecology (cf. Dr. Du'an Plut, Slovenija in sonaravna evropska politika, Regionalizem (Slovenia and Sustainable European Policy, Regionalism), 1998, p. 33) provides a good example in showing how endangered European standards can become when small independent municipalities incapable of development sell off agricultural land at low prices and consent to the destruction of the(ir) environment in order to solve their unenviable financial difficulties.

There is no doubt that the negative effects of the fragmentation of local self-government in Slovenia are all the more fatal precisely because there exists no other level of wider local self-government. If the period from independence to the present has been devoted to the fragmentation of Slovenia, it is high time that after its accession to the European Union, Slovenia begins to deal with integration based on decentralization. If up until now a great deal of attention has been paid to the horizontal division of authority between the legislative, executive and judicial branches of power, we should, from now on, pay more attention to the vertical division of authority (between the central authority and local self-government). The establishment of regions can significantly contribute to such a development.

This leads us to the European aspects in the narrow sense. The absence of regions is particularly painful with regard to the country's accession to the European Union. We are dealing with accession to a single economic area in which the free movement of goods, services, ideas and persons is the norm. In these new circumstances every part of Slovenia is under the direct influence of a foreign environment. In conditions of open co-operation and free competition, the disadvantages in organisation become increasingly evident and dangerous, far more than previously, when state borders still protected them.

Warnings over the consequences of the invalid organisation of local selfgovernment have been voiced early and clearly enough: "If Slovenia joins the European Union with invalid organisation, it will not be prepared for the abolition of classical borders with Italy, Austria and Hungary, and a few years later with Croatia." (Ribičič: 2003, p. 45) Let us quote another near-dramatic warning: Slovenia should not join the European Union without regions; an adequately organized Slovenia may achieve "the ideal of a united Slovenia in a 


\section{Ciril Ribičič}

\section{European aspects of the regionalization of Slovenia}

united Europe; otherwise the integration of Slovenia into the European Union will lead to the subordination of the large part of the territory inhabited by the Slovenians to foreign political interests and capital" (Regionalism, 1998, p. 228). The warnings have not been taken into account; thus it is all the more important to make up for all that has been lost as soon as possible. We have to take full advantage of the additional time available to Slovenia, because certain aspects of the opening up of borders and integration of the Slovenian market into the European one are being implemented with a delay (integration in the Schengen area, integration in the euro area, elimination of obstacles to the free movement of workers in older EU Member States etc.). But the time for doing this passes quickly.

The second European aspect in the narrow sense relates to the (in)ability of Slovenia to successfully compete for European funds. Generally, European funds are not granted to the state or local communities recklessly but for the realization of concrete projects. It is precisely at the regional level that we can realistically expect that people and municipalities will be able to pool their efforts for the preparation of such quality programmes which will be (co)financed by European Union structural funds. It is evident at first sight that the vast majority of municipalities are not adequately trained in this respect. This is also why we need to speed up the establishment of regions.

The problem of ensuring a more uniform regional development of Slovenia is related to this aspect. Developmental differences between the centre of the country and border regions which are turning into peripheries will continue to increase unless regions are established to which an important part of economic power and responsibility for development are transferred. European funds for the less developed can help significantly in this respect, whereby it is evident that Slovenia as a whole will be increasingly less entitled to such funds due to its developed central region, while additional development incentives are necessary and universally justified for the great majority of other Slovenian regions. Slovenia does not have to artificially establish regions on grounds of speculation in respect of the utilisation of EU funds for which Ireland, as a case in point, has been criticized, because in the case of Slovenia there are convincing internal reasons for their establishment.

Regions could promote their individual and common development (cf. Bugarič, B., Ekonomski vidiki regionalizma (Economic Aspects of Regionalism), in: Regionalizem (Regionalism), 1998, p. 121), in connection with suitable local communities in neighbouring countries which fragmented municipalities are not able to do. Let us not even begin to address the extent to which Slovenia can today participate on an equal footing in the establishment of cross-border 
Euro-regions together with regions in the neighbouring countries which are all organized at the regional level.

The amendment of Article 143 of the Constitution opens up the process for the establishment of regions which has been advocated for the past 15 years in numerous initiatives, analyses, consultations and collections of scientific papers. Our attention needs to be future-oriented. It is therefore important to emphasize that it is not acceptable to establish regions in some highly arbitrary fashion. The two-thirds majority necessary for the adoption of the most important legislation related to the establishment of regions ensures that the arrangement which rests on narrow interests of governing political structures (elecoral geometry) or the expropriation of municipalities will not be met? There still remain two other threats.

Experiences with excessive fragmentation of municipalities raises justified concerns that similar tendencies might also arise in respect of the establishment of regions. This would not only be questionable from the point of view of the fundamental European guidelines but also contrary to the concrete warnings of the Council of Europe experts that regions in Slovenia not have less than 100,000 inhabitants.

Another equally important threat is that the establishment of regions would be used for a more effective control and subordination of local communities to the state and its administration. Croatian experiences in the area of the development of counties point to the threat that wider local selfgovernment may be deformed in such a way that it becomes an obedient extension of the state bureaucracy. This warning should be seriously taken into account when considering the status of regions as amphibians which would be, at the same time, wider self-governing local communities and administrative regions.

Once regions are established and become fully operative, the issue of their representation and influence on the decision-making process in the national parliament will be re-opened. It must not be forgotten that in the former Yugoslav federation, Slovenia placed the greatest emphasis on the polycentric

6 An overview of regional authority organisation in the European Union Member States between the central state authority and smaller local communities: Vlaj, Decentralizacija, Evropa in mi (Decentralisation, Europe and Us), in: Pokrajina (Region): 2004, p. 158.

7 The research group at the Institute for Public Administration at the Faculty of Law in Ljubljana (dr. Rajko Pirnat, dr. Franc Grad, dr. Gorazd Trpin, dr. Senko Pličanič and Erik Kerševan, LL M) prepared an overview of the tasks and competences which would be transferred to regions by the state. The overview comprised hundreds of tasks and competences defined in over 50 acts (Dokumenti in 'tudije o pokrajinah v Sloveniji 2000-2004 (Documents and Studies on Regions in Slovenia 2000-2004), (ed. R. Lavtar), Ministry of the Interior, Ljubljana, 2004, p. $265 \mathrm{ff})$. 


\section{Ciril Ribičič \\ European aspects of the regionalization of Slovenia}

development and influence of local communities on the state decision-making processes (municipal delegates' meeting, Chamber of Municipalities). Even in the process of adopting the Constitution in the period 1990-1991, there existed a proposal for the establishment of a regional chamber as the second parliamentary chamber which would strengthen the influence of local and regional interests at the expense of the excessive influence of the leading circles of political parties in the National Assembly. In the transitional period the regions will be able to exert their influence on the National Assembly's decisionmaking process through the National Council.

To sum up, the establishment of regions in a way which would lead to new fragmentation and divisions and the strengthening of state bureaucracy instead of the integration and strengthening of presently weak local selfgovernment would be another wrong move from both the European and Slovenian perspectives.

Dr. Ciril Ribičic is the judge of the Constitutional Court of the Republic of Slovenia and he is a full-time professor of constitutional law at the Ljubljana University Law School, where he has continuously taught for thirty years. He is the author of numerous treaties in the area of constitutional law. He has been the president of the Ljubljana Law School Constitutional Law Department and the president of the Constitutional Law Society. Within the framework of the constitutional commission preparing the new constitution, he conducted an expert group on state systems. Upon a proposal by the Constitutional Law Department, he was elected constitutional judge on 19 December 2000. 


\section{Sources}

- Bugarič, B. (1998): Ekonomski vidiki regionalizma. V: Regionalizem v Sloveniji. Str. 121-130. Zbirka Pravo in politika. Uradni list Republike Slovenije, Ljubljana.

- Cerar, M., Perenič, G., ed. (2001): Nastajanje slovenske ustave, Izbor gradiv Komisije za ustavna vprašanja, III. zvezek, Ljubljana.

- Kocjančič, R., Ribičič, C., Grad, F., Kaučič, I. (2005): Ustavno pravo, Fakulteta za upravo, Ljubljana.

- Lavtar, R. (2004): Deset let lokalne samouprave: vizija 1994, praksa 2004. 199 str. Skupnost občin Slovenije, Maribor.

- Plut, D. (1998): Slovenija in sonaravna evropska politika. V: Slovenija: pokrajine in ljudje. 735 str., Mladinska knjiga, Ljubljana.

- Ribičič, C. (1998): Regionalizem v Sloveniji: zbornik. 284. str. Zbirka Pravo in politika. Uradni list Republike Slovenije, Ljubljana.

- Ribičič, C. (1994): Centralizem zoper Slovenijo. Ljubljana,.

- Ribičič, C. (2003): Mozaik ustavnih sprememb, PP, Ljubljana.

- Šmidovnik, J. (1995): Lokalna samouprava. Zbirka: Pravna obzorja 4, 274 str. Cankarjeva založba, Ljubljana.

- Vlaj, S. (2001): Vodnik po slovenski lokalni samoupravi. 136 str., Inštitut za lokalno samoupravo pri Visoki upravni šoli, Ljubljana.

- Vlaj, S. (2004): Pokrajina: druga raven lokalne samouprave. 161 str. Inštitut za lokalno samoupravo pri Fakulteti za upravo, Ljubljana.

- Vlaj, S. (2004): Lokalna samouprava: teorija in praksa. / Spremenjena in dopolnjena izd./ 376 str. Fakulteta za upravo, Ljubljana.

- Vlaj, S. (2004): Decentralizacija, Evropa in mi. V: Pokrajina: druga raven lokalne samouprave. str. 158. Inštitut za lokalno samoupravo pri Fakulteti za upravo, Ljubljana. 